\title{
Impact of meteorological parameters and air pollution on emergency department visits for cardiovascular diseases in the city of Zagreb, Croatia
}

\author{
Sanja Pintarić1 ${ }^{1}$ Ivan Zeljković ${ }^{2}$, Gordana Pehnec ${ }^{3}$, Višnja Nesek $^{4,7}$, Mislav Vrsalović2,5, and \\ Hrvoje Pintarić 2,6 \\ First School of Economics ${ }^{1}$, University Hospital Centre Sisters of Charity ${ }^{2}$, Institute for Medical Research and \\ Occupational Health ${ }^{3}$, University Hospital Holy Spirit ${ }^{4}$, School of Medicine ${ }^{5}$, School of Dental Medicine, University \\ of Zagreb, Zagreb, School of Medicine, Josip Juraj Strossmayer University of Osijek, Osijek', Croatia
}

[Received in January 2016; CrossChecked in January 2016; Accepted in July 2016]

\begin{abstract}
The aim of this study was to investigate whether nitrogen dioxide $\left(\mathrm{NO}_{2}\right)$, ozone $\left(\mathrm{O}_{3}\right)$, and certain meteorological conditions had an impact on cardiovascular disease (CVD)-related emergency department (ED) visits in the metropolitan area of Zagreb. This retrospective, ecological study included 20,228 patients with a cardiovascular disease as their primary diagnosis who were examined in the EDs of two Croatian University Hospitals, Sisters of Charity and Holy Spirit, in the study period July 2008-June 2010. The median of daily CVD-related ED visits during the study period was 28 and was the highest during winter. A significant negative correlation was found between CVD-related emergency visits and air temperature measured no more than three days prior to the visit, and the highest negative correlation coefficient was measured two days earlier $(\mathrm{R}=0.266, \mathrm{p} \leq 0.001)$. The number of CVD-related emergency visits significantly correlated with the average $\mathrm{NO}_{2}$ concentration on the same day $(\mathrm{R}=0.191, \mathrm{p}<0.001)$. The results of multiple stepwise regression analysis showed that the number of CVD-related emergency visits depended on air temperature, and $\mathrm{NO}_{2}$ and $\mathrm{O}_{3}$ concentrations. The higher the air temperatures, the lower the number of daily CVD-related emergency visits $(\mathrm{p}<0.001)$. An increase in $\mathrm{NO}_{2}$ concentrations $(\mathrm{p}=0.005)$ and a decrease in $\mathrm{O}_{3}$ concentrations of two days earlier $(\mathrm{p}=0.006)$ led to an increase in CVD-related ED visits. In conclusion, the decrease in $\mathrm{O}_{3}$ concentrations and the increase in $\mathrm{NO}_{2}$, even if below the legally binding thresholds, could be associated with an increase in CVD-related emergency visits and a similar effect was observed with lower temperature measured no more than three days prior to the visit.
\end{abstract}

KEY WORDS: atmospheric humidity; atmospheric pressure; nitrogen dioxide; ozone; temperature

In recent years, many studies and reviews have tried to identify and prove the effect of air pollution on cardiovascular diseases and explain the pathogenesis of this influence (1-4). Furthermore, several studies have shown that air pollution represents a great health risk even in developed countries with legally defined thresholds of air pollution (4-6). Cardiovascular diseases are the main mortality and morbidity cause both worldwide and in Croatia (5); it has been shown to an increasing extent that air pollution significantly contributes to worsened cardiovascular health (2-6). Zagreb, the capital of Croatia, is located in the northwest of the country, has a maritime temperate climate or oceanic climate $(\mathrm{Cfb}$ in the Köppen-Geiger climate classification system), and generally features four separate seasons with warm summers and cool (but not cold) winters and a relatively narrow annual temperature range. Around 1.2 million people live in a wider Zagreb metropolitan area, which accounts for more than $20 \%$ of Croatia's population,

Correspondence to: Ivan Zeljković, University Hospital Centre Sisters of Charity, Vinogradska 29, 10000 Zagreb, Croatia;

E-mail:ivanzeljkov@gmail.com making it the only metropolitan area in Croatia with a population of over one million and consequently an area with occasional higher levels of traffic-related pollution (7).

Nitrogen dioxide $\left(\mathrm{NO}_{2}\right)$ is both a primary and a secondary pollutant, as well as a strong respiratory irritant. Its main outdoor sources are motor vehicles and fossil-fuel power plants, whereas the most important indoor sources are gas heaters, stoves, and tobacco smoke $(5,6)$. Many studies and meta-analyses underlined the association between daily increases in $\mathrm{NO}_{2}$ and cardiovascular and respiratory mortality and morbidity $(1,5,6)$. Ozone $\left(\mathrm{O}_{3}\right)$ is a secondary pollutant created indirectly in the troposphere from its precursors, e.g. oxides of nitrogen and volatile organic compounds. In urban areas, the main sources of ozone precursors are combustion engines. A few studies have shown its association with hospital admissions for cardiovascular and respiratory diseases $(8,9)$. For many cardiovascular conditions, however, as few as $10 \%$ of those examined in the emergency department (ED) were admitted to hospital (9-11) whereas the remaining $90 \%$ were treated in the ED but were not hospitalised. Thus, the number of ED visits reflects the impact of air pollution on CVD 
population better than the number of hospitalised patients $(10,11)$.

The aim of this study was to investigate whether nitrogen dioxide, ozone, and certain meteorological conditions impacted CVD-related emergency visits in the metropolitan area of Zagreb over a period of two years. It is noteworthy to disclose that this study follows on a previously published similar study in which the impact of atmospheric air pollution by $\mathrm{NO}_{2}$ and meteorological parameters on a number of patients examined in EDs was studied (12); however, this study also includes the impact of ozone and the population of the metropolitan area of Zagreb which is almost twice as large in comparison with the previous study, the data of which were gathered from one hospital only.

\section{METHODS}

In the study period between July 2008 and June 2010 77,532 patients were examined in the EDs of two hospitals: Sisters of Charity University Hospital Centre and Holy Spirit University Hospital. The study population included 20,228 patients with a cardiovascular disease as their primary diagnosis, classified as I00-I99 according to the $10^{\text {th }}$ International Classification of Diseases (ICD-10). The data on patients' emergency department visits were extracted from the hospitals' electronic system, which is used in both hospitals' EDs. During the entire research period, this system was used to record the data on patients older than 18 years who were examined in EDs due to a cardiovascular disease. Patients without permanent residency in Zagreb and patients without a confirmed I00-I99 diagnosis were excluded from the study.

This retrospective ecological study aimed to evaluate the association (hourly, daily, and earlier days) between meteorological conditions, air pollutant levels, and cardiovascular patients referred to EDs during the study period. The number of CVD-related emergency visits was compared with meteorological conditions and $\mathrm{NO}_{2}$ and $\mathrm{O}_{3}$ air concentrations during the overall period of the study, as well as during seasons only. Seasons were determined by weather conditions and not by calendar division as follows: winter $=$ December to February, spring $=$ March to May, summer $=$ June to August, autumn $=$ September to November.

\section{Environmental data}

Air pollution data were taken from the State Network for Continuous Air Quality Monitoring. The concentration of $\mathrm{NO}_{2}$ was measured daily with automatic analyser using the method of chemiluminescence at the monitoring stations Zagreb-1, Zagreb-2, and Zagreb-3 and were averaged. The concentrations of $\mathrm{O}_{3}$ were measured only at Zagreb-1 due the fact that it is the only station measuring $\mathrm{O}_{3}$ levels in Zagreb, using an automatic analyser based on the method of ultraviolet photometry (UV absorption at $254 \mathrm{~nm}$ ). The measurements were performed at a height of 3 meters with the data integration frequency of one hour. The 8-hour and 24-hour averages were based on the hourly concentrations of $\mathrm{NO}_{2}$ and $\mathrm{O}_{3}$ and were analysed as such. Meteorological data: atmospheric temperature $\left({ }^{\circ} \mathrm{C}\right)$, atmospheric pressure $(\mathrm{hPa})$, and relative atmospheric humidity $(\%)$ were based on the data collected at a Meteorological and Hydrological Service of Croatia's meteorological station that covers the area of Zagreb in which the population gravitating to the study EDs lives. The meteorological data were converted from hourly values to daily averages so as to compare them with CVD-related emergency visits.

Since this was a retrospective ecological study, written informed consent was not necessary according to local legislation. The study protocol complied with Good Clinical Practice as well as the Declaration of Helsinki and the Hospital Ethics Committee provided its approval of the study.

\section{Statistical analysis}

Descriptive statistics were presented as the mean \pm standard deviation and median with the interquartile range and the analysis focused on the correlation between CVD-related ED visits, air pollutants, and meteorological factors. The mean values of individual variables were tested by a nonparametric Mann-Whitney test, which included two samples, and a non-parametric analysis of KruskalWallis ANOVA for multiple samples. Data distribution was analysed using logarithms for the variables whose distribution was not normal. The correlation between the number of patients and each of the meteorological variables and air pollutants was tested by non-parametric Spearman's rank correlation. The influence of a group of variables on the number of CVD-related emergency visits was tested by multiple stepwise regression analysis. A value of $\mathrm{p}<0.05$ was considered statistically significant. Statistical analysis was done using the STATISTICA software, version 6.0 for Windows (Dell Software, StatSoft Inc., Tulsa, USA).

\section{RESULTS}

In the study period of two years, or 730 days, 77,532 patients were examined in the EDs of the two hospitals. According to the ICD-10 classification (I00-I99 diagnosis, which includes acute coronary syndrome, ischaemic heart disease, congestive heart failure, and arrhythmias), 20,228 patients were diagnosed with a cardiovascular disease. The median of the daily number of patients examined in EDs during the observation period was 107 and there were 28 CVD-related emergency visits. Table 1 shows the meteorological parameters, pollutant concentrations, and ED visits during the whole study period and seasons only. 
Table 1 Meteorological parameters, air pollutant concentrations, and number of cardiac patients' ED visits during the whole study period and during seasons

\begin{tabular}{|c|c|c|c|c|c|c|}
\hline & $\begin{array}{l}\text { Entire study } \\
\text { period }\end{array}$ & Spring & Summer & Autumn & Winter & $\begin{array}{c}\text { Kruskal- } \\
\text { Wallis } \\
\text { ANOVA }\end{array}$ \\
\hline & $\begin{array}{c}\text { Median } \\
(25 \%-75 \%)\end{array}$ & $\begin{array}{c}\text { Median } \\
(25 \%-75 \%)\end{array}$ & $\begin{array}{c}\text { Median } \\
(25 \%-75 \%)\end{array}$ & $\begin{array}{c}\text { Median } \\
(25 \%-75 \%)\end{array}$ & $\begin{array}{c}\text { Median } \\
(25 \%-75 \%)\end{array}$ & $\mathrm{p}$ value \\
\hline $\begin{array}{l}\text { Temperature } \\
\left({ }^{\circ} \mathrm{C}\right)\end{array}$ & $\begin{array}{c}13.4 \\
(-7.9-28.5)\end{array}$ & $\begin{array}{c}13.8 \\
(-1.2-26.5)\end{array}$ & $\begin{array}{c}22.5 \\
(13.3-28.5)\end{array}$ & $\begin{array}{c}13.1 \\
(1.0-25.4)\end{array}$ & $\begin{array}{c}2.6 \\
(-7.9-14.5)\end{array}$ & $\mathrm{p}<0.001$ \\
\hline $\begin{array}{l}\text { Relative } \\
\text { humidity (\%) }\end{array}$ & $\begin{array}{c}68.9 \\
(37.7-95.3)\end{array}$ & $\begin{array}{c}60.7 \\
(37.7-91.4)\end{array}$ & $\begin{array}{c}61.5 \\
(41.0-89.5)\end{array}$ & $\begin{array}{c}73.5 \\
(44.4-95.3)\end{array}$ & $\begin{array}{c}78.9 \\
(43.6-94.0)\end{array}$ & $\mathrm{p}<0.001$ \\
\hline $\begin{array}{l}\text { Air pressure } \\
(\mathrm{hPa})\end{array}$ & $\begin{array}{c}996 \\
(966-1020)\end{array}$ & $\begin{array}{c}997 \\
(966-1009)\end{array}$ & $\begin{array}{c}996 \\
(984-1004)\end{array}$ & $\begin{array}{c}998 \\
(979-1013)\end{array}$ & $\begin{array}{c}994 \\
(971-1020)\end{array}$ & $\mathrm{p}<0.001$ \\
\hline $\begin{array}{l}\mathrm{NO}_{2}-\text { hourly } \\
\text { average }\left(\mu \mathrm{g} \mathrm{m}^{-3}\right)\end{array}$ & 22.3 & 19.9 & 20.0 & 25.7 & 24.2 & $\mathrm{p}<0.001$ \\
\hline $\begin{array}{l}\mathrm{NO}_{2}-\text { daily } \\
\text { average }\left(\mu \mathrm{g} \mathrm{m}^{-3}\right)\end{array}$ & 25.9 & 24.7 & 24.2 & 30.7 & 26.8 & $\mathrm{p}<0.001$ \\
\hline $\begin{array}{l}\mathrm{O}_{3}-\text { hourly } \\
\text { average }\left(\mu \mathrm{g} \mathrm{m}^{-3}\right)\end{array}$ & 41.5 & 59.4 & 60.3 & 29.4 & 25.0 & $\mathrm{p}<0.001$ \\
\hline $\begin{array}{l}\mathrm{O}_{3}-\text { daily } \\
\text { average }\left(\mu \mathrm{g} \mathrm{m}^{-3}\right)\end{array}$ & 48.0 & 57.7 & 59.5 & 36.5 & 27.1 & $\mathrm{p}<0.001$ \\
\hline $\begin{array}{l}\text { Average daily } \\
\text { number of } \\
\text { cardiac patients } \\
\text { examined in ED }\end{array}$ & $\begin{array}{c}28 \\
(9-53)\end{array}$ & $(9-53)$ & $\begin{array}{c}24 \\
(10-44)\end{array}$ & $\begin{array}{c}29 \\
(14-45)\end{array}$ & $\begin{array}{c}30 \\
(12-46)\end{array}$ & $\mathrm{p}<0.001$ \\
\hline $\begin{array}{l}\text { Total number of } \\
\text { cardiac patients } \\
\text { examined in ED }\end{array}$ & $20228(100)$ & $5294(26.1)$ & $4455(22.0)$ & $5209(25.8)$ & $5270(26.1)$ & $\mathrm{p}<0.001$ \\
\hline
\end{tabular}

\section{Meteorological parameters}

The daily average of CVD-related emergency visits was the highest in winter season (Table 1). Moreover, nonparametric analysis (Spearman's correlation coefficient) showed that during the observation period CVD-related emergency visits significantly correlated to the air temperature measured no more than three days prior to the visit. The coefficient was negative, meaning that the lower the temperature the higher the number of CVD-related emergency visits. The highest negative correlation coefficient was found with the average temperature measured two days earlier $(\mathrm{R}=0.266, \mathrm{p}<0.001)$. The average relative air humidity of the same day positively correlated to CVD-related emergency visits $(R=0.113, p=0.002)$. The average air pressure of the same day negatively correlated to the number of CVD-related emergency visits, but this correlation was not statistically significant $(R=0.056, p=0.131)$. Regarding the values of meteorological indicators by the observation period and by seasons, the lowest temperatures were recorded in winter with average $2.6^{\circ} \mathrm{C}$ and the highest ones in summer $\left(21.9^{\circ} \mathrm{C}\right)$. The lowest atmospheric pressure was recorded in winter $(994 \mathrm{hPa})$, and the highest in autumn
(998 hPa) but without statistical significance, whereas the highest relative humidity was recorded in winter (80\%) and in autumn (75\%), with significant correlation between higher relative humidity and lower temperatures (Table 2).

\section{The nitrogen-oxide $\left(\mathrm{NO}_{2}\right)$ effect}

The highest daily values of air $\mathrm{NO}_{2}$ were recorded in winter and the lowest in summer. During the two-year observation period, the hourly values of $\mathrm{NO}_{2}$ concentrations never exceeded the legally binding threshold of $200 \mu \mathrm{g} \mathrm{m}^{-3}$ set by Croatian and EU legislation (EU Directive 2008/50/ $\mathrm{EC})$. The $\mathrm{NO}_{2}$ threshold for the averaging time of one year is $40 \mu \mathrm{g} \mathrm{m}^{-3}$, and it was not exceeded during the first year (1 July 2008 - 30 June 2009; $27.5 \mu \mathrm{g} \mathrm{m}^{-3}$ ), nor during the second

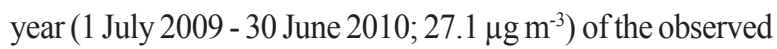
period. The number of CVD-related emergency visits significantly correlated to the average $\mathrm{NO}_{2}$ concentration on the same day $(\mathrm{R}=0.191, \mathrm{p}<0.001)$. $\mathrm{NO}_{2}$ concentrations of previous days did not have a statistically significant effect on the number of CVD-related emergency visits (Table 3). 
Table 2 Correlations between meteorological parameters and air pollutant concentrations during the study period

\begin{tabular}{lccccc} 
& $\begin{array}{c}\text { Air temperature } \\
\left({ }^{\circ} \mathbf{C}\right)\end{array}$ & $\begin{array}{c}\text { Air pressure } \\
(\mathbf{h P a})\end{array}$ & $\begin{array}{c}\text { Relative } \\
\text { humidity }(\%)\end{array}$ & $\mathbf{N O}_{2}\left(\mu \mathbf{~ m}^{-3}\right)$ & $\mathbf{O}_{3}\left(\boldsymbol{\mu} \mathbf{g m}^{-3}\right)$ \\
\hline $\begin{array}{l}\text { Air temperature } \\
\left({ }^{\circ} \mathrm{C}\right)\end{array}$ & - & $-0.194^{*}$ & $-0.455^{*}$ & 0.010 & $0.657^{*}$ \\
\hline Air pressure $(\mathrm{hPa})$ & $-0.194^{*}$ & - & 0.000 & -0.030 & $-0.127^{*}$ \\
\hline $\begin{array}{l}\text { Relative humidity } \\
(\%)\end{array}$ & $-0.455^{*}$ & 0.000 & - & -0.031 & $-0.637^{*}$ \\
\hline $\left.\mathrm{NO}_{2}(\mu \mathrm{g} \mathrm{m})^{-3}\right)$ & 0.010 & -0.030 & -0.031 & - & $-0.384^{*}$ \\
\hline $\mathrm{O}_{3}\left(\mu \mathrm{g} \mathrm{m}^{-3}\right)$ & $0.657^{*}$ & $-0.127^{*}$ & $-0.637^{*}$ & $-0.384^{*}$ & - \\
\hline
\end{tabular}

* p value $<0.05$

The ozone $\left(\mathrm{O}_{3}\right)$ effect

The highest hourly values of $\mathrm{O}_{3}$ were recorded in summer (Table 1). The median hourly averages for the observation period amounted to $41.5 \mu \mathrm{g} \mathrm{m}^{-3}$, and the highest were recorded in summer $\left(60.3 \mu \mathrm{g} \mathrm{m}^{-3}\right)$. The highest daily averages were recorded in spring with the maximum of $126 \mu \mathrm{g} \mathrm{m}^{-3}$, which is also the maximum for the whole observation period. The maximum eight-hour average concentration of $\mathrm{O}_{3}$ for the two-year observation period was $160.4 \mathrm{\mu g} \mathrm{m}^{-3}$ and was recorded in summer. The medians of eight-hour moving averages were calculated, recording the highest values in spring and summer (59.4 and $59.6 \mu \mathrm{g} \mathrm{m}^{-3}$ ).

The number of days with a maximum daily eight-hour mean of $\mathrm{O}_{3}$ values higher than $120 \mu \mathrm{g} \mathrm{m}^{-3}$ (which is the target value according to the EU Directive 2008/50/EC) was specified. According to Croatian legislation, the maximum daily eight-hour moving average of $\mathrm{O}_{3}$ concentrations should not exceed $120 \mu \mathrm{g} \mathrm{m}^{-3}$ on more than 25 calendar days, averaged over three years. During the two-year observation period, the number of days with ozone values above $120 \mu \mathrm{g} \mathrm{m}^{-3}$ was 38 , out of which most were recorded in summer (24 days), whereas not a single day was recorded in winter. Considering the World Health Organization's (WHO) recommendation on the threshold of $100 \mu \mathrm{g} \mathrm{m}^{-3}$, the number of days with eighthour concentration averages above $100 \mu \mathrm{g} \mathrm{m}^{-3}$ was 166 , out of which most were recorded in summer (81 days). During the observation period there was a statistically significant negative correlation between $\mathrm{O}_{3}$ and relative humidity $(\mathrm{R}=-$ $0.637, p<0.001)$ as well as air pressure $(R=-0.127, p=0.001)$ (Table 2). The number of CVD-related emergency visits significantly negatively correlated to the average $\mathrm{O}_{3}$ concentration on the same day, as well as up to three days earlier (Table 4). However, the correlation coefficient between the number of ED cardiac patients and the air temperature measured two days earlier was -0.266 , whereas the correlation to $\mathrm{O}_{3}$ concentrations measured two days earlier was significantly lower, amounting to -0.126 . Meanwhile, the correlation coefficient between the temperature and $\mathrm{O}_{3}$ amounted to 0.572 regarding the daily average, or even 0.737 regarding the maximum hourly $\mathrm{O}_{3}$ values within a day.

\section{Multiple stepwise regression analysis}

The results of multiple stepwise regression analysis showed that the number of CVD-related emergency visits significantly depended on three variables: air temperature, $\mathrm{NO}_{2}$ concentration, and $\mathrm{O}_{3}$ concentration. The higher the air temperatures, the lower the number of CVD-related emergency visits $(\mathrm{r}=-0.09)$. The increase in $\mathrm{O}_{3}$ concentrations was also associated with a decrease in CVD-related emergency visits $(\mathrm{r}=-0.190, \mathrm{p}=0.006)$. Moreover, an increase in $\mathrm{NO}_{2}$ concentrations was associated with an increase in CVD related emergency visits $(\mathrm{r}=0.055)$.

\section{DISCUSSION}

In this study, we investigated the impact of air pollutants together with meteorological parameters on the number of CVD-related emergency visits. Our data revealed that air pollutant levels and air temperature were associated with the number of CVD-related emergency visits. A significant increase in the daily number of CVD-related emergency visits was associated with increased $\mathrm{NO}_{2}$ air concentrations lower $\mathrm{O}_{3}$ concentrations on the same day, and lower air temperature measured no more than three days prior to the visit, with the highest negative correlation coefficient measured two days earlier.

The observed meteorological values were as expected, considering Zagreb's latitude and climate zone. According to our results, there was a negative correlation of air temperature and the number of CVD-related emergency visits throughout the whole observed period. Mean daily air temperature did not exceed $22.5^{\circ} \mathrm{C}$ and most likely for that reason positive correlation was not found in the warmest part of the year. Moreover, the negative correlation coefficient in the warmest part of the year was undoubtedly the least pronounced. In many cities with $\mathrm{Cfb}$ climate, as in Zagreb, the mortality rate of cardiovascular disorders during winter 
months is up to $25 \%$ higher than in summer months, and air temperature fluctuations cause increased morbidity and mortality from cardiovascular diseases $(13,14)$. In the winter period, the longer the low temperature period the higher the risk, while in the warm part of the year increased air temperatures affect directly the risk of cardiovascular incidents (13-15). Numerous scientific studies have presented air temperature as the main parameter, with any accompanying air pollutant, which highly affects the risk of cardiovascular incidents (14-17), as confirmed by the results of our work.

Schwarz et al. (18) found that in 12 United States cities, covering a wide range of different geographical regions, the effects of relative humidity on ED cardiac visits were small, almost statistically insignificant, but the effects of low and high temperatures were high, especially with myocardial infarction. They concluded that the effects mainly occurred within a few days after exposure (usually two days) and ceased within ten days after exposure. The results of our study coincide with the results of their work, with an exception that the average relative humidity had a positive correlation coefficient with the number of ED visits of cardiac patients.

Although the levels of $\mathrm{NO}_{2}$ have not exceeded the legally binding threshold values, there was a significant association between $\mathrm{NO}_{2}$ concentration and the number of CVD-related emergency visits, especially in winter time when weather conditions favour the emergence of higher $\mathrm{NO}_{2}$ concentrations. In our study, the strongest correlation was found with average daily values of $\mathrm{NO}_{2}$ measured on the same day. This result shows that ambient $\mathrm{NO}_{2}$ concentrations, which are below the legally binding limit values, strongly affect the number of CVD-related emergency visits, which was confirmed in several previous studies (19-21).

Several review studies $(2,9,22)$ showed that $\mathrm{O}_{3}$ was one of the most toxic compounds of mixed photochemical smog. Results of our study revealed a negative correlation between $\mathrm{O}_{3}$ concentrations and CVD-related emergency visits, which is in line with previous studies (22-24). However, many studies showed destructive effects of this pollutant on the cardiovascular system. A study by Koken et al. (25) has proved in the city of Denver, which has a cold continental climate, a significant association of high temperatures and high $\mathrm{O}_{3}$ values with CVD-related emergency visits, especially with acute myocardial infarction and cardiac arrhythmias. Similar to this, Shahi et al. (26) indicated that a growing number of cardiac patients examined in the emergency departments of the capital city of Tehran were recorded on the third day after two days of increased concentrations of ozone.

According to our findings, which are in agreement with most previous similar studies, health care systems need to be ready to control and treat diseases arising from air pollution. Data on the number of patients admitted is vital in ensuring suitable equipment and facilities proportionate to the number of admitted patients. On the other hand, because of the differences in pollutant levels of various geographical locations, the pattern of hospital admissions is noticeably different in days of greater pollution. Therefore, it is critical that health care systems of countries are informed about the pattern of hospital admissions and polluted days to have more accurate managing programmes for this crisis. Also, the need for improved legal regulations and lower upper legally binding threshold values of air pollution should be emphasised, because air pollution that is within the permitted legal levels is associated with the increase in CVD-related emergency visits, which was confirmed in our study, especially for $\mathrm{NO}_{2}$.

\section{Limitations}

Although the study period was rather short, there were no exceptional events that could have influenced the results. The study was based on a population as large as 1.2 million

Table 3 Cardiovascular disease related-emergency visits over a period of 692 days correlated with nitrogen-dioxide (NO$)$ concentrations

\begin{tabular}{lcc}
\hline & $\begin{array}{c}\text { Correlation } \\
\text { coefficient } \mathbf{R}\end{array}$ & p value \\
\hline maximum hourly $\mathrm{NO}_{2}$ concentration & 0.072 & 0.057 \\
\hline average daily $\mathrm{NO}_{2}$ concentration & 0.191 & $<0.001$ \\
\hline average daily $\mathrm{NO}_{2}$ concentration 1 day earlier & 0.034 & 0.378 \\
\hline average daily $\mathrm{NO}_{2}$ concentration 2 days earlier & -0.037 & 0.329 \\
\hline average daily $\mathrm{NO}_{2}$ concentration 3 days earlier & -0.009 & 0.804 \\
\hline
\end{tabular}

Table 4 Cardiovascular disease-related emergency visits over a period of 646 days correlated with ozone $\left(O_{3}\right)$ concentrations

\begin{tabular}{lcc}
\hline & $\begin{array}{c}\text { Correlation } \\
\text { coefficient } \mathbf{R}\end{array}$ & p value \\
\hline maximum hourly $\mathrm{O}_{3}$ concentration & -0.183 & $<0.001$ \\
\hline average daily $\mathrm{O}_{3}$ concentration & -0.191 & $<0.001$ \\
\hline average daily $\mathrm{O}_{3}$ concentration 1 day earlier & -0.132 & 0.0007 \\
\hline average daily $\mathrm{O}_{3}$ concentration 2 days earlier & -0.126 & 0.0014 \\
\hline average daily $\mathrm{O}_{3}$ concentration 3 days earlier & -0.108 & 0.0061 \\
\hline
\end{tabular}


inhabitants, among which daily CVD-related emergency visits were quite frequent and reached the number of 28 , which ensured the statistical power of the analysis. However, the results of the study should be considered in the light of certain limitations. The $\mathrm{O}_{3}$ data was taken from only one monitoring station, which may lead to the misclassification of exposure level. However, this misclassification is non-differential and should bias the effect estimates towards the null. Moreover, as with every ecological study, there is a lack of precise exposure estimates at individual level and misclassification of exposure due to different daily activity patterns and local mobility of each patient and the deduction of cause-effect relations should be done with caution. Additionally, there are large scale factors that may influence CVD rates and CVD-related emergency visits which were not taken into account.

In conclusion, to the authors' knowledge this was the first study in Croatia that investigated the influence of air pollution, including nitrogen dioxide $\left(\mathrm{NO}_{2}\right)$ and ozone $\left(\mathrm{O}_{3}\right)$, and certain meteorological parameters on emergency department visits of patients with cardiovascular diseases.

The authors report no conflict of interest.

\section{Acknowledgments}

The authors are grateful to Professor Ivana Zeljkovic for her valuable expert assistance with the English language. Moreover, the authors appreciate the cooperation of the emergency departments' staff of the University Hospital Centre Sisters of Charity and University Hospital Holy Spirit, Zagreb, Croatia.

\section{REFERENCES}

1. Lipsett MJ, Ostro BD, Reynolds P, Goldberg D, Hertz A, Jerrett M, Smith DF, Garcia C, Chang ET, Bernstein L. Longterm exposure to air pollution and cardiorespiratory disease in the California teachers study cohort. Am J RespirCrit Care Med 2011;184:828-35. doi: 10.1164/rccm.201012-2082OC

2. Bell ML, Dominici F, Samet JM. A meta-analysis of timeseries studies of ozone and mortality with comparison to the national morbidity, mortality, and air pollution study. Epidemiology 2005;16:436-45. PMCID: PMC3581312

3. Le Tertre A, Medina S, Samoli E, Forsberg B, Michelozzi P, Boumghar A, Vonk JM, Bellini A, Atkinson R, Ayres JG, Sunyer J, Schwartz J, Katsouyanni K. Short-term effects of particulate air pollution on cardiovascular diseases in eight European cities. J Epidemiol Community Health 2002;56:7739. doi: $10.1136 /$ jech.56.10.773

4. Basagaña X, Jacquemin B, Karanasiou A, Ostro B, Querol $\mathrm{X}$, Agis D, Alessandrini E, Alguacil J, Artiñano B, Catrambone M, de la Rosa JD, Díaz J, Faustini A, Ferrari S, Forastiere F, Katsouyanni K, Linares C, Perrino C, Ranzi A, Ricciardelli I, Samoli E, Zauli-Sajani S, Sunyer J, Stafoggia M; MED-PARTICLES Study group. Short-term effects of particulate matter constituents on daily hospitalizations and mortality in five South-European cities: results from the MED-PARTICLES project. Environ Int 2015;75:151-8. doi: 10.1016/j.envint.2014.11.011

5. Brunekreef B, Holgate ST. Air pollution and health. Lancet 2002;360:1233-42. doi: 10.1016/S0140-6736(02)11274-8

6. Samoli E, Aga E, Touloumi G, Nisiotis K, Forsberg B, Lefranc A, Pekkanen J, Wojtyniak B, Schindler C, Niciu E, Brunstein R, Dodic Fikfak M, Schwartz J, Katsouyanni K. Short-term effects of nitrogen dioxide on mortality: an analysis within the APHEA project. Eur Respir J 2006;27:1129-38. doi: 10.1183/09031936.06.00143905

7. Croatian Bureau of Statistics. Census of Population, Households and Dwellings 2011 [displayed 6 July 2016]. Available at http://www.dzs.hr/default_e.htm

8. World Health Organization (WHO). The 10 leading causes of death by broad income group, 2004. Geneva: WHO; 2004.

9. Gryparis A, Forsberg B, Katsouyanni K, Analitis A, Touloumi G, Schwartz J, Samoli E, Medina S, Anderson HR, Niciu EM, Wichmann HE, Kriz B, Kosnik M, Skorkovsky J, Vonk JM, Dörtbudak Z. Acute effects of ozone on mortality from the "air pollution and health: a European approach" project. Am J Respir Crit Care Med 2004;170:1080-7. doi: 10.1164/ rccm.200403-333OC

10. Stieb DM, Judek S, Burnett RT. Meta-analysis of time-series studies of air pollution and mortality: effects of gases and particles and the influence of cause of death, age, and season. J Air Waste Manag Assoc 2002;52:470-84. doi: 10.1080/10473289.2002.10470794

11. Stieb DM, Szyszkowicz M, Rowe BH, Leech JA. Air pollution and emergency department visits for cardiac and respiratory conditions: a multi-city time-series analysis. Environ Health 2009;8:25. doi: 10.1186/1476-069X-8-25

12. Pintarić S, Bodrožić-Džakić T, Pintarić H, Rusan Z, Ljubičić $\mathrm{S}$. Effects of nitrogen dioxide and meteorological conditions on the number of patients presenting to emergency department. Acta Clin Croat 2012;51:9-15. PMID: 22919997

13. Wang XY, Barnett AG, Yu W, FitzGerald G, Tippett V, Aitken P, Neville G, McRae D, Verrall K, Tong S. The impact of heatwaves on mortality and emergency hospital admissions from non-external causes in Brisbane, Australia. Occup Environ Med 2012;69:163-9. doi: 10.1136/oem.2010.062141.

14. Nayha S. Cold and the risk of cardiovascular diseases. A review. Int J Circumpolar Health 2002;61:373-80. PMID: 12546195

15. Liu L, Breitner S, Pan X, Franck U, Leitte AM, Wiedensohler A, von Klot S, Wichmann HE, Peters A, Schneider A. Associations between air temperature and cardio-respiratory mortality in the urban area of Beijing, China: a time-series analysis. Environ Health 2011;10:51-65. doi: 10.1186/1476069X-10-51

16. Baccini M, Kosatsky T, Analitis A,Anderson HR, D'Ovidio M, Menne B, Michelozzi P, Biggeri A; PHEWE Collaborative Group. Impact of heat on mortality in 15 European cities: attributable deaths under different weather scenarios. J Epidemiol Community Health 2011; 65:64-70. doi: 10.1136/ jech.2008.085639

17. Wang MZ, Zheng S, He SL, Li B, Teng HJ, Wang SG, Yin L, Shang KZ, Li TS. The association between diurnal temperature range and emergency room admissions for cardiovascular, respiratory, digestive and genitourinary disease among the elderly: a time series study. Sci Total 
Environ 2013;456-457:370-5. doi: 10.1016/j. scitotenv.2013.03.023

18. Schwartz J, Samet JM, Patz JA. Hospital admissions for heart disease: the effects of temperature and humidity. Epidemiology 2004;15:755-61. doi: 10.1097/01.ede.0000134875.15919.0f

19. Metzger KB, Tolbert PE, Klein M,Peel JL, Flanders WD, Todd K, Mulholland JA, Ryan PB, Frumkin H. Ambient air pollution and cardiovascular emergency department visits. Epidemiology 2004;15:46-56. doi: 10.1097/01. EDE.0000101748.28283.97

20. Vanos JK, Hebbern C, Cakmak S. Risk assessment for cardiovascular and respiratory mortality due to air pollution and synoptic meteorology in 10 Canadian cities. Environ Pollut 2014;185:322-32. doi: 10.1016/j.envpol.2013.11.007

21. Tong L, Li K, Zhou Q. Promoted relationship of cardiovascular morbidity with air pollutants in a typical Chinese urban area. PLoS One 2014;9:e108076. doi: 10.1371/journal.pone. 0108076
22. Srebot V, Gianicolo E, Rainaldi G, Trivella MG, Sicari R. Ozone and cardiovascular injury. Cardiovasc Ultrasound 2009;7:30. doi: 10.1186/1476-7120-7-30

23. Levy JI, Chemerynski SM, Sarnat JA. Ozone exposure and mortality: an empiric bayesmeta regression analysis. Epidemiology 2005;16:458-68. PMID: 15951663

24. Qorbani M, Yunesian M, Fotouhi A, Zeraati H, Sadeghian S, Rashidi Y. Relation between air pollution exposure and onset of acute coronary syndrome in Tehran Heart Center using a case-crossover design. Iran J Epidemiol 2007;3:53-9.

25. Koken PJ, Piver WT, Ye F, Elixhauser A, Olsen LM, Portier CJ. Temperature, air pollution, and hospitalization for cardiovascular diseases among elderly people in Denver. Environ Health Perspect 2003;111:1312-7. doi: 10.1289/ ehp.5957

26. Shahi AM, Omraninava A, Goli M, Soheilarezoomand HR, Mirzaei N. The effects of air ollution on cardiovascular and respiratory causes of emergency admission. Emergency (Tehran) 2014;2:107-14. PMCID: PMC4614571

\section{Utjecaj meteoroloških parametara i onečišćenja zraka na preglede u Hitnoj službi zbog kardiovaskularnih bolesti u gradu Zagrebu, Hrvatska}

Cilj istraživanja bio je ispitati imaju li dušikov dioksid $\left(\mathrm{NO}_{2}\right)$, ozon $\left(\mathrm{O}_{3}\right)$ i određene meteorološke prilike utjecaja na broj pregleda u Hitnoj službi (HS) zbog kardiovaskularnih bolesti (KVB) u gradu Zagrebu. U ovu retrospektivnu, ekološku studiju bilo je uključeno 20.228 bolesnika s primarnom dijagnozom jedne od kardiovaskularnih bolesti, pregledanih $u$ HS-u dviju kliničkih bolnica: Sestre milosrdnice i „Sveti Duh“, u promatranom razdoblju od srpnja 2008. do lipnja 2010. Medijan dnevnih pregleda u HS-u zbog KVB-a tijekom promatranog razdoblja bio je 28, a najviše tijekom zime. Značajna negativna korelacija utvrđena je između broja pregleda u HS-u zbog KVB-a i temperature zraka do tri dana ranije, $s$ najvećim negativnim koeficijentom korelacije dva dana ranije $(\mathrm{R}=-0,266, \mathrm{p}=0,000)$. Broj pregleda $\mathrm{u}$ HS-u zbog KVB-a značajno korelira s prosječnim koncentracijama $\mathrm{NO}_{2}$ na isti dan $(\mathrm{R}=0,191, \mathrm{p}=0,000)$. Rezultati stupnjevite regresijske analize pokazali su da broj pregleda u HS-u zbog KVB-a ovisi o temperaturi zraka i koncentraciji $\mathrm{NO}_{2} \mathrm{i} \mathrm{O}_{3}$. Š to je viša temperatura zraka, to je manji broj pregleda u HS-u zbog KVB-a $(p=0,000)$, a slično vrijedi i za koncentraciju ozona $(\mathrm{p}=0,006)$. Povećanje koncentracije $\mathrm{NO}_{2}$ povezano je s povećanjem broja pregleda u HS-u zbog KVB-a $(\mathrm{p}=0,005)$. Zaključno se može ustvrditi da povećanje koncentracije $\mathrm{NO}_{2}$ može biti povezano s povećanjem broja pregleda u HS-u zbog KVB-a, čak ako su navedene koncentracije unutar pravnoobvezujućih razina, sa sličnim utjecajem niže temperature zraka do tri dana ranije. 